Sitorus, T., \& Yuganda, K. (2019). Investor's stock selection decision: influence of profitability, company size, and RAROC. Copernican Journal of Finance \& Accounting, 8(2), 67-86. http:// dx.doi.org/10.12775/CJFA.2019.009

Tigor Sitorus*

Universitas Bunda Mulia

Kendo Yuganda**

Universitas Bunda Mulia

\title{
INVESTOR'S STOCK SELECTION DECISION: INFLUENCE OF PROFITABILITY, COMPANY SIZE, AND RAROC
}

Keywords: LQ45, stock, selection, decision, investor, RAROC, profitability, size.

J E L Classification: G210.

Abstract: This study aims to investigate and analyze the investor's stock selection decision that are influenced by profitability, company size, and RAROC on the companies listed on the Indonesia Stock Exchange. The sampling method used was purposive sampling. The sample in this study were companies listed on the LQ-45 Index for the period 2015-2017. This study used structural equation model analysis (SEM) with AMOS software version 22.00 against 108 financial report data from 36 companies that were listed in the LQ-45 Index in a row for 3 years as a sample. The results of this study indicate that; 1). Investor's stock selection decision are influenced positively and significantly by profitability, 2). Investor's stock selection decision are influenced negatively and not significantly by company size. 3). Investor's stock selection decision is affected negatively and not significantly by RAROC.

Date of submission: July 5, 2019; date of acceptance: July 30, 2019.

* Contact information: sitorus_tigor@yahoo.com, Universitas Bunda Mulia, North Jakarta City, Jakarta, Indonesia, phone: +62216929090; ORCID ID: https://orcid. org/0000-0001-7477-9537.

** Contact information: kendoyuganda09@gmail.com, Universitas Bunda Mulia, North Jakarta City, Jakarta, Indonesia, phone: +628119133009. 


\section{INTRODUCTION}

The capital market is a place where companies that have gone public and the number of investors or prospective investors want to buy shares from various types of companies (Hadi, 2015). Companies that have gone public issue their shares to obtain fresh funds from the public and investors. Public shares can be bought and sold in the community. The reasons for companies going public, namely allowing the founder to diversify business, facilitate the purchase of other companies (expansion), and the value of the company going public allows the community and management to know the value of the company. Stocks are influenced by the level of supply and demand on the Indonesia Stock Exchange.

A business activity that is run by a company, certainly has several objectives to be achieved by the owner and management. First, the owner of the company wants optimal profits or the business it runs. Therefore, every owner wants the capital invested in his business to quickly return. In addition, the owner also expects the results of the capital that has been invested so that it can provide additional capital and prosperity for the owner and all of his employees.

Investment is an investment activity that can get one or more assets carried out by individuals or institutions, in the hope of getting a return in the future. Techniques in conducting investment analysis that are widely used are technical analysis and fundamental analysis. Technical analysis uses price history charts and transaction lists. This analysis is related to studying the historical performance of stock price movements by measuring future price movements. Fundamental analysis is an analytical method that pays attention to economic factors that will influence the development of a company (Jagongo \& Mutswenje, 2014).

In addition to technical and fundamental factors, experts see investors' market behavior also comes from psychological principles of decision making to explain why people buy or sell stocks, such as; Shefrin (2000) examines the influence of psychology on the behavior of financial practitioners, while Nofsinger and Richard (2002) examine individual investment behaviors related to the choice of small purchases of securities for their own accounts.

Empirically, many companies listed on the Indonesia Stock Exchange benefit the company's business wheels in the company's balance sheet. The better the profit a company they have will make it easier for the company to develop an increase in the capacity of the profits obtained. Similarly, the size of the company, is experiencing developments from local and national companies to 
become global companies. But there is a tendency for large companies to experience a shock due to a hostile capital market. In just a few minutes, the profits of large companies included in the LQ- 45 group, eroded by the JCI which fell sharply or the value of the dollar exchange rate that often fluctuated.

The LQ-45 index is an index consisting of 45 stocks selected through various criteria such as; have high liquidity and high transaction volume. This makes LQ-45 shares highly favored by capital investors even individual or company in Indonesia, thus becoming a benchmark for the development of capital markets on the Indonesia Stock Exchange. Based on empirical phenomena obtained from data released by the Indonesia Stock Exchange (www1), that over a period of 3 years (2015-2017), the majority of outstanding LQ-45 shares did not experience growth or stagnate also decline, that is impacted to Issuer's profit, thus affecting investors to buy shares belonging to the LQ- 45 group. Profitability is the ability of a company to generate profits for a certain period.

According to Riyanto (2008), To measure the development of the company, the Company must pay attention to financial performance aspects which include equity value, sales value, and asset value. Companies that have many assets will be able to increase production capacity which has the potential to generate better profits, therefore the value of assets as a measure of the company is considered to affect the profitability of a company, but on the contrary larger company assets will increase costs more, thereby reducing profitability. Furthermore, to make the company more developed and increase profitability, companies need to add capital from funding activities in the form of loans. Company capital can be obtained from internal and external parties. If the internal party cannot fulfill the company's capital, the company will borrow from external parties who are able to provide company capital. The use of external funds by the company can result in the company getting problems regarding the company's ability to fulfill financial obligations.

Some of the results of previous studies indicate differences (research gap) such as, Rahmawati, Topowijono and Sulasmiyati (2015) research and Yulindar (2017) state that profitability has a positive and significant effect on firm value and investor's stock selection decision, but Anisyah and Purwohandoko (2017) states that profitability has a negative effect, furthermore the research about company size conducted by Yulindar (2017) which states that company size has a positive and significant effect on firm value and investor's stock selection decision, but research conducted by Dewi and Wirajaya (2013) also Rahmawa- 
ti, Topowijono and Sulasmiyati (2015) has difference results, where the results of their study state that the size of the company has a negative effect.

This research is different from previous studies such as: Nurmalasari (2008) who examined the Effect Analysis of Profitability Ratios on Issuer LQ45 Stock Prices, and Rahmawati, Topowijono and Sulasmiyati (2015) who examined the relationship of Firm Size, Profitability, Capital Structure, and Investor's decision against corporate values, while this study examined relations profitability, company size and Raroc with the investor's stock selection decision of LQ-45.

Based on the explanation that mention above, the researcher chose the LQ-45 company as the research object because it has promising prospects in the future for investors to invest their funds, so the problems that will be examined in this study are; 1). Is the investor's stock selection decision influenced by profitability, 2). Is the investor's stock selection decision influenced by company size, 3). Is the investor's stock selection decision influenced by the Raroc.

\section{LITERATURE REVIEW}

\section{Background Theory}

\subsection{Investor's Stock Selection Decision}

According to Samsul (2006, p. 146), investment is the placement of a number of funds at this time in the hope of gaining profits in the future. There are two factors considered in decision making by the investor, namely the rate of return and risk. Investment in the capital market is in dire need of sufficient knowledge, experience, and business instincts to analyze which effects will be purchased, which ones will be sold and which ones will remain. In conducting transactions in the capital market, a very important thing to consider for an investor is the valuation of stock prices in addition to the condition of the economy and the issuer. Stock prices are formed by the existence of market demand and market supply. The difference between the current value and the value of the market becomes an investor's reference in getting profits and determining investment decision.

Stock valuation can be done using two analyzes, namely technical analysis and fundamental analysis. Technical analysis is an analysis that observes stock price movements over time. According to Sunariyah (2006, p. 168), technical 
analysis is an analysis technique that uses data or records about the market itself to try to access the demand and supply of a particular stock or market as a whole.

According to Hermuningsih (2012, p. 194), fundamental analysis is an attempt to analyze various factors related to stocks that will be selected through company analysis, industry analysis and other methods that support the analysis to be chosen.

\subsection{Profitability}

According to Kasmir (2010, p. 196), profitability is a measure to assess a company's ability to make a profit. Profitability is used to measure the extent of the effectiveness of overall management in creating profits for the company. The greater the level of profitability, the better for the company itself. The higher the level of profitability of a company, the greater the level of prosperity provided by the company will attract investors to own the company and will have a positive impact on stock prices on the market.

ROA is a financial indicator that describes the company's ability to generate profits on the total assets of the company (Darmadji \& Fakhruddin, 2011). The higher the ROA, the better the company is able to use assets to gain profits and the greater the ROA, which means that the more efficient the use of the company or in other words the same amount of assets can produce greater profits and vice versa. The formula for return on assets (ROA) equal Net Profit divided by Total Asset.

Furthermore, Weston and Brigham (2001, p. 101) states that "Return on Equity (ROE) is the ratio of net income to common equity: measures of the ratio of returns on common stockholders's investment". According to Mardiyanto (2009, p. 196) ROE is a ratio used to measure the success of a company in generating profits for shareholder. ROE is considered as a representation of shareholder wealth or company value. Return on equity (ROE) is a ratio that shows the company's ability to generate post-tax profits by using the company's own capital. This ratio is to determine the effectiveness and efficiency of the processing of own capital carried out by the management of the company (Harahap, 2007).

In Liestyana (2008), this ROE shows the extent to which a company manages its own capital effectively, measures the level of profits from investments that have been made by the owners of their own capital or the company's share- 
holders. ROE shows the profitability of own capital or what is often referred to as business profitability. As for the return on equity (ROE) formula equal Net Profit divided by Owner's equity.

Net profit margin (NPM) is a financial indicator in the profitability ratio. According to Bastian, Indra dan Suhardjono (2006, p. 299) in Rinati (2009), net profit margin (NPM) is a comparison of net income and sales. The greater the NPM, the more effective the company's performance will be, so that it will increase investor confidence to invest in the company. This ratio shows how large the percentage of net income earned from each sale. The greater the NPM ratio, the better the company's ability to earn high profits. The relationship between net income and net sales shows the management's ability to drive the company successfully enough to leave a certain margin as reasonable compensation for owners who have provided capital to a risk. The NPM ratio can be interpreted as the company's ability to reduce costs in a certain period of time. A high net profit margin indicates a company's ability to generate certain sales-level profits, a low net profit margin indicates that sales are too low for a certain level of cost, while the formula for the net profit margin (NPM) is Net profit after tax divided by Sales.

\subsection{Company Size}

Companies that have large sizes have the flexibility and accessibility to obtain funds from the capital market. The convenience is captured by investors as a positive signal and good prospect so that it can provide a positive influence on the value of the company. Investors consider the variable size of the company as one of the rationalizations in making investment decision Sartono (2010). The greater the value of total sales, total assets, and market capitalization, the greater the size of the company. The greater the total assets, the more capital invested, the more sales, the more money flows and the greater the market capitalization, the greater the company will be known in the community (Sudarmadji \& Sularto, 2007). Therefore, small-scale companies have a smaller risk than large companies. Companies that have greater risk usually offer large returns to attract investors. The formula used for company size, namely: Ln Total Asset. 


\subsection{Stock Risk}

According to Brigham and Houston (2014), risks are defined in Webster dictionaries as "a hindrance, disruption, exposure to loss or accident". So the risk is interpreted as an opportunity for the occurrence of an unwanted event. Risk can also be interpreted as a possible difference between the actual return received and the expected return. Stock investment risk consists of non-systematic risk (unsystematic risk) and systematic risk (systematic risk). Non-systematic risks or commonly referred to as unique risks are risks associated with the fluctuations and business cycles of certain industries. Thematic risk (systematic risk) related to market conditions, so-called market risk. Systematic risk is a risk that cannot be reduced even with a diversification process.

In a stock investment risk there are many ways to determine risk by determining the value of RAROC (Risk Adjusted Return on Capital). According to Prokopczuk, Rachev and Trueck (2004, pp. 3-4), the RAROC was developed by the Banker Trust in the late 1970s, which aimed to measure risk by considering the trade-off between risk and income from different assets and activities. In calculating RAROC using the following formula:

\section{RAROC $=\Sigma R-\beta(R m-R)$}

Where:

$\Sigma \mathrm{R}=$ Expected Return,

$\mathrm{B}=$ Beta,

$\mathrm{Rm}=$ Return Market,

$\mathrm{R}=$ stock return.

\section{DEVELOPMENT OF HYPOTHESES}

From various studies that have been done before and based on the framework of thinking and directing to researchers, then in this study hypotheses will be proposed as follows: 


\subsection{Profitability has a positive influence on stock selection decision}

Research conducted by Yulindar (2017) states that profitability has a positive and significant effect on firm value and stock selection decision. Likewise with the research conducted by Rahmawati, Topowijono and Sulasmiyati (2015) which states that profitability has a positive effect on firm value and stock selection decision. The greater the level of profitability, the better for the company itself. The higher the level of profitability of a company, the greater the level of prosperity provided by the company will attract investors to have the company and will have a positive impact on stock prices on the market (Brigham \& Houston, 2014).

\subsection{Company size has a positive influence on stock selection decision}

Research conducted by Yulindar (2017) states that firm size has a positive and significant effect on firm value and stock selection decision. Companies that have large size have flexibility and accessibility to obtain funds from the capital market. The convenience is captured by investors as a positive signal and good prospect so that it can provide a positive influence on the value of the company.

\subsection{RAROC has a negative influence on stock selection decision}

According to Fuss and Vermeulen (2004), Peltonen (2013) states that there is a negative association between fundamental risk and future profitability also Putra (2014), the hypothesis of this study which states that the risk systematically affects the expected stock return, is acceptable. The higher the level of systematic risk, the higher the level of expected return and stock selection decision. The results of this analysis indicate that the systematic risk of each share will affect the level of expected return. The existence of systematic risk will cause changes in stock prices in the capital market which will indirectly result in changes in the expected return.

Based on various theories and the development of the hypotheses described above, the following model framework is presented below: 
Figure 1. Model Design of research

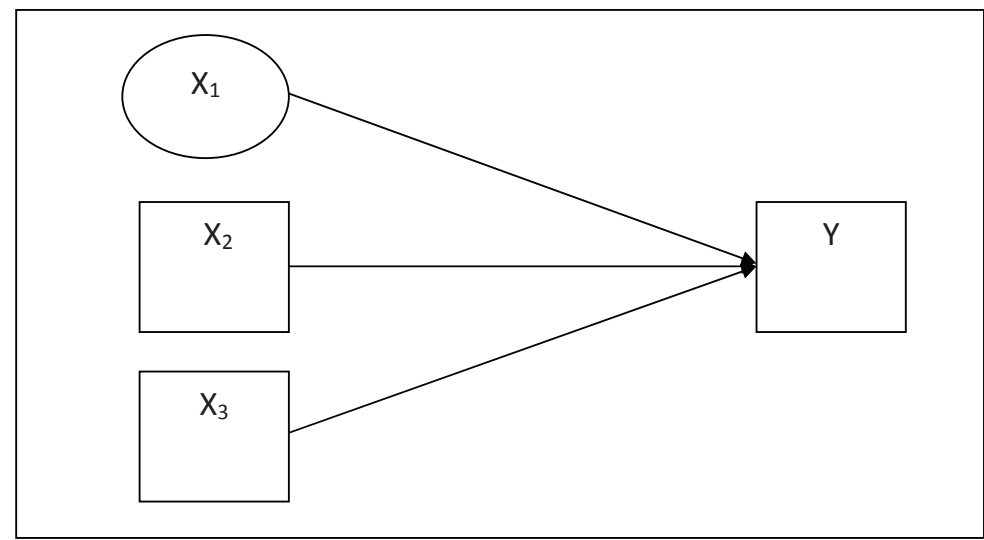

Notes:

$\mathrm{Y}=$ Stock selection decision

$\mathrm{X} 1$ = Profitability (ROA, ROE, NPM)

$\mathrm{X} 2$ = Company size

$\mathrm{X} 3=\mathrm{RAROC}=\boldsymbol{\Sigma} \mathbf{R}-\boldsymbol{\beta}(\mathbf{R m}-\mathbf{R})$

S o u r c e : model research developed by authors.

\section{THE RESEARCH METHODOLOGY \\ AND THE COURSE OF THE RESEARCH PROCESS}

\section{Types of research}

The type of research used by researchers is explanatory research with a quantitative approach (Nazir, 2014).

\section{Location of Data Acquisition}

This study uses data obtained from Indonesia Stock Exchange (IDX, www2), which is located in the Indonesia Stock Exchange Building, Tower 1, 6th floor. Jl. Jendral Sudirman Kav 52-53. South Jakarta 12190. 


\section{Population, Samples, and Sampling Techniques}

The population of this study is the LQ-45 company listed on the Indonesia Stock Exchange in the period 2015-2017, which has a complete financial report and published on the Indonesian stock exchange totaling 45 companies

The sample in this study was determined through non probability sample techniques with purposive sampling method and selected 36 companies. The Sample Criteria and Selection are as follows:

a) Companies included in the LQ45 Index during the period 2015-2017

b) Companies that do not report financial statements end at December 31 during the period 2015-2017

c) Companies that have suffered losses or more during 2015-2017 = -7

d) Companies whose shares are not listed during the period 2015-2017 $=-1$

e) The number of companies used as samples

f) Number of observational data $=36$ $=3 \times 36=108$ data

\section{Data analysis technique}

The test in this study uses the Structural Equation Model (SEM) Test, Ferdinand Augusty (2005). SEM is a statistical model that provides an estimate of the strength of a hypothetical relationship between variables in a theoretical model, either directly or through an intermediate variable. SEM is used to analyze the relationship between one latent variable with another latent variable known as a structural equation. The processing of data in this study uses version 22.00 of the Amos (Analysis of moment structure) program. According to Ferdinand (2005) on testing the model using SEM with the suitability of the upper model: $\chi 2$ - Chi Square statistics, RMSEA (Root Mean Square Error of Approximation), GFI (Goodness of fit Index), AGFI (Adjusted Goodness of Fit Index), CMIN / DF (The Minimum Sample Discrepancy Function Devided with Degree of Freedom), TLI (Tucker Lewis Index), CFI (Comparative Fit Index).

While testing the maximum likelihood estimation (the estimated effect test between variables) is done with mathematical equation models such as the following: 


$$
\begin{aligned}
& Y=f(X 1)+f(X 2)+f(X 3)+e \\
& X 1=f(X 11)+f(X 12)+f(X 13)+e
\end{aligned}
$$

\section{RESULTS AND DISCUSSION}

\section{Data Normality Test}

Data normality testing is done by observing the value of CR unvariately, if the value of the critical ratio is unvariate between -2.58 to 2.58 , then normal distribution can be categorized.

Table 1. Normality Assessment

\begin{tabular}{|l|c|c|c|c|c|c|}
\hline \hline \multicolumn{1}{|c|}{ Variable } & min & $\max$ & skew & c.r. & kurtosis & c.r. \\
\hline \hline SIZE & 12.02078 & 32.21492 & .47976 & 2.03544 & -.61137 & -1.29691 \\
\hline RAROC & -1084.96991 & 195.77819 & -8.93491 & -37.90760 & 85.25894 & 180.86152 \\
\hline VT & -1.00000 & 27.21922 & 6.32180 & 26.82114 & 42.39284 & 89.92880 \\
\hline NPM & .00360 & .49930 & .91043 & 3.86264 & .20536 & .43564 \\
\hline ROE & .00420 & 1.60990 & 3.63339 & 15.41516 & 13.19163 & 27.98367 \\
\hline ROA & .00230 & .45790 & 1.87253 & 7.94448 & 2.96944 & 6.29913 \\
\hline Multivariate & & & & & 131.19676 & 69.57759 \\
\hline \hline
\end{tabular}

S o u r c e : results of processing AMOS 22.0 data.

Based on table 1, it can be seen that the results of multivariate c.r normality are known at 69.5776, which is more than 2.58. So it can be concluded that the distribution of this study is not normal. Although the distribution of this data is not normal, it can still be used to predict the relationship between independent variables and dependent variables. 


\section{SEM Test}

In this study a model of fit was tested to test the feasibility of the model used in this study.

Table 2. Model Test Results

\begin{tabular}{|c|c|c|c|c|}
\hline No & Goodness-of Fit Index & Cut Off Value & Result & Criteria \\
\hline 1 & $\mathrm{X} 2 \mathrm{Chi}$-Square $(\mathrm{df}=)$ & $<a . d f$ & 5.776 & Fit \\
\hline 2 & Probability & $\geq 0.05$ & 0.448 & Fit \\
\hline 3 & CMIN/DF & $\leq 2.00$ & 0.962 & Fit \\
\hline 4 & GFI & $\geq 0.90$ & 0.982 & Fit \\
\hline 5 & AGFI & $\geq 0.90$ & 0.983 & Fit \\
\hline 6 & $\mathrm{CFI}$ & $\geq 0.95$ & 1.000 & Fit \\
\hline 7 & TLI & $\geq 0.95$ & 1.003 & Fit \\
\hline 8 & $\mathrm{IFI}$ & $\geq 0.90$ & 1.001 & Fit \\
\hline 9 & RMSEA & $\leq 0.08$ & 0.000 & Fit \\
\hline 10 & $\mathrm{NFI}$ & $\geq 0.90$ & 0.965 & Fit \\
\hline 11 & Hoelter & $\leq 200$ & 234 & Marginal fit \\
\hline
\end{tabular}

S o u r c e : results of processing AMOS 22.0.

Based on table 2 data above, it can be concluded that the overall model used in this study fulfills the goodness-off fit criteria which means that this model can be used to estimate the effect of independent variables on the dependent variable, with the following explanation:

1) Chi-Square $(\chi 2)$ is 5.776 with a significant level of $p 50.05$ which means there is no difference because Chi-Square is very sensitive to the sample used. While the Chi-Square table shows the number 133.257, and it can be concluded that the results of the Chi-Square model are smaller than the results.

2) Probability of $p=0.448$ which means that it has met the criteria of model fit which is greater than 0.05 .

3) CMIN / DF value is one indicator to measure the fit level of a model. CMIN / DF is the chi-square statistic, $\chi 2$ divided by Df so that it is called $\chi^{2}$ 
- relative. CMIN / DF or $\chi 2$ - the expected relative is $\leq 2.00$. From the results of the study, the CMIN / DF value is 0.962 and can meet the criteria of good fit.

4) GFI is a conformity index that will calculate the weighted proportion of variance in the sample covariance matrix described by the estimated population covariance matrix. GFI has a range of values between 0 (poor fit) up to 1.0 (perfect fit). From the results of this study, the GFI value is 0.982 , so this model has met the criteria of good fit.

5) AGFI is a criterion that takes into account the weighted proportion of variance in a sample covariance matrix. AGFI value of 0.95 can be interpreted to produce a good level while the magnitude of the AGFI value between 0.90-0.95 shows a sufficient level. So that the expected AGFI is $\geq 0.90$. So the results of this research model amounted to 0.983 then this model has met the criteria of good fit.

6) CFI is an index whose size is not influenced by sample size because it is very good for measuring the level of acceptance of a model. CFI is in the range of $0-1$. The expected CFI is $\geq 0.95$.

7) TLI is an alternative incremental fit index that compares a model tested against a model baseline. The expected TLI is $\geq 0.95$. The results of this study model are 1,003, so this model has met the criteria of good fit.

8) IFI (Incremental Fit Index) value ranges from 0 to 1 , IFI value $\geq 0.90$. The results of this study model are 1,001, then this model has met the criteria of good fit.

9) RMSEA is an index that can be used to compile chi-square statistics in large samples. The RMSEA value indicates goodness-of-fit that can be expected if the estimation model is in the population. RMSEA value that is smaller or equal to 0.08 is an index that meets the criteria of good fit. The results of this research model are 0,000 , so this model has met the criteria of good fit.

10) NFI (Normal Fit Index) is a measure of comparison between the proposed model and the null model, used for small numbers of samples. NFI value $\geq 0.90$. The results of this study model are 0.965 , so this model meets the criteria of good fit.

11) Hoetler to measure the model, the value of the calculation results is 234 , so it is above 200 , so the model can be said to be not fit. 


\section{Maximum likelihood estimation test (hypothesis Testing)}

Table 3. Hypothesis Testing

\begin{tabular}{|l|c|l|c|c|c|c|c|}
\hline \hline & & & Estimate & S.E. & C.R. & P & Label \\
\hline \hline ROA & $<---$ & PR & 1.00000 & .24012 & 2.41223 & $* * *$ & Accepted \\
\hline ROE & $<---$ & PR & 1.11074 & .44015 & 4.79546 & $* * *$ & Accepted \\
\hline NPM & $<--$ & PR & .17877 & .10352 & 1.72687 & .04419 & Accepted \\
\hline VT & $<--$ & PR & 5.94117 & 3.04091 & 1.95375 & .05073 & Accepted \\
\hline VT & $<---$ & SIZE & -.01891 & .06187 & -.30554 & .75995 & Rejected \\
\hline VT & $<---$ & RAROC & .00320 & .00295 & 1.08605 & .27746 & Rejected \\
\hline \hline
\end{tabular}

S o u r c e : results of processing AMOS 22.0 data.

Notes:

PR = Profitability,

SIZE = Total Asset,

RAROC = Risk Adjusted Return on Capital,

$\mathrm{VT}=$ Stock selection decision,

$\mathrm{ROA}=$ Return on Asset, ROE = Return on Equity, NPM = Net Profit Margin.

The structural equation produced by the fit model formed from AMOS 22.0 output is as follows:

Investor's Stock selection decision $=$ 5,941 PR - 0,018 SIZE + 0,003 RAROC

Profitability $=1,000$ ROA $+1,110$ ROE + 0,178 NPM

Based on the third structural equation model (3), it can be seen that if the PR variable rises by one unit and the other variables remain, the Investor's stock selection decision variable will increase by 5.941 units, if the SIZE variable drops one unit and the other variable remains, the transaction volume variable will increase by 0.018 units, and RAROC variable increases by one unit and the other variables remain, then the transaction volume variable will increase by 
0.003. Furthermore based on fourth model (4) of structural equation, it can be seen that if the ROA variable rises by one unit and the other variables remain, the profitability variable will increase by 1,000 units, if the ROE variable increases by one unit and the other variables remain, the profitability variable will increase by 2.110 units, and if the NPM variable up one unit and the other variables remain, the profitability variable will increase by 0.178 units.

Based on table 3 that mention above, then bellow is presented the following hypothesis testing:

\section{a) The influence of profitability on stock selection decision (H1)}

The results of the study prove that stock selection decision are influenced positively and significantly by profitability with a coefficient of 5.941 and a significance value of 0.05 , where profitability is proxyed by ROA, ROE, NPM with a factor loading value greater than 0.70 except NPM $0.178<0.70$. This means that ROA and ROE are very strong to form company Profitability at LQ-45, so that it can be said that H1 is accepted which means that stock selection decision are influenced positively and significantly by profitability or profitability variable has a direction in line with the stock selection decision variable. This result is in accordance with Ramarow (2017) that states the risk elements that affects the profitability, also Hermuningsih $(2012$, p. 194) which states that fundamental analysis is an attempt to analyze various factors related to stocks which will be selected through company analysis, industry analysis, and research conducted by Yulindar (2017) stating that profitability has a positive effect and significant to company value and stock selection decision. Likewise with the research conducted by Rahmawati, Topowijono and Sulasmiyati (2015) which states that profitability has a positive effect on firm value and stock selection decision, because before investing, investors need to know and choose which stocks can provide the most optimal benefits for the funds invested. Stock prices also reflect the value of a company. If the company achieves good performance, then the shares will be in great demand by investors. Issuers are obliged to publish financial statements for a certain period, where financial statements are very useful for investors to assist in making investment decision, such as selling, buying, or planting shares. In a study conducted by Nurmalasarai $(2008$, p. 6). Return On Assets (ROA) has a significant effect on stock prices where when profit before tax rises and total assets 
go down, the ROA will increase. ROE on stock prices does not have a significant effect, and for NPM it also has no significant influence and negative relationship.

\section{b) The influence of Company Size on Stock Selection Decision (H2)}

The results of the study prove that stock selection decision are influenced negatively and not significantly by firm size with a coefficient of -0.018 and a significance value of 0.759 , where firm size is proxied by the value of ln Asset. This means that the magnitude of the company's assets does not significantly influence the decision of stock selection, or the size of the company is not a consideration for investors to invest, so it can be said that $\mathrm{H} 2$ is rejected which means that the stock decision is not significantly affected by company size or size which is in line with the stock selection decision variable. This is in accordance with the results of research conducted By Constantinou, Karali and Papanastasopoulos (2017) that examines whether firm-level asset investment effects in returns found for U.S. firms occur within the Greek stock market and find that growth in total assets is strongly negatively related to future stock returns and will impact to stock seletion of Greek firms also by Dewi and Wirajaya (2013) where company size has no significant effect and Rahmawati, Topowijono and Sulasmiyati (2015) has conflicting results, where firm size has a negative effect.

\section{c) The influence of Raroc on stock selection decision (H3)}

The results of the study prove that stock selection decision are influenced positively and not significantly by Raroc with a coefficient of 0.003 and a significance value of 0.227 , where Raroc is proxy by the value of Stock Risk. This has the meaning that the amount of stock risk does not significantly influence the decision of stock selection. or Stock Risk is not a consideration for investors to invest, so that it can be said that $\mathrm{H} 3$ is rejected, which means that the stock selection decision is not significantly affected by Stock Risk or Stock Risk does not have a movement in line with the stock selection decision variable. This is in accordance with the results of a study conducted by Prabowo (2013) where stock risk has a negative influence on stock selection because in the negative RAROC value there is a risk or loss where the total profit is smaller than the average loss. 


\section{CONCLUSIONS AND IMPLICATION}

Stock selection decision are influenced positively and significantly by profitability, proxy profitability is ROA, ROE, NPM has high loading factors forming profitability except NPM. This proves the acceptance of the hypothesis in this study and simultaneously answers the problem of the influence of profitability on stock selection decision. This result supports Ramarow (2017), Yulindar (2017), Rahmawati, Topowijono and Sulasmiyati (2015), Hermuningsih (2012, p. 194) stating that profitability has a positive and significant effect on firm value and stock selection decision.

Stock selection decision are influenced negatively and insignificantly by company size, the size of the company is proxy by the Asset value. This proves the rejection of the hypothesis in this study and simultaneously answers the problem of the influence of company size on stock selection decision. This finding is in accordance with the results of research conducted by Constantinou, Karali and Papanastasopoulos (2017), Dewi and Wirajaya (2013) where firm size has no significant effect and Rahmawati, Topowijono and Sulasmiyati (2015) has conflicting results, where firm size has a negative effect.

Stock selection decision are influenced positively but not significantly by Raroc where Raroc is proxy by the value of Stock Risk. This proves the rejection of the hypothesis in this study and simultaneously answers the problem of the effect of stock risk on stock selection decision. or Stock Risk is not a consideration for investors to invest. This is in accordance with the results of research conducted by Peltonen (2013), Prabowo (2013) that stock risk has a negative influence on profitability and impacted to stock selection because in a negative RAROC value there is a risk or loss where the total profit is smaller than average loss.

Academically, this study contributes so that the research model of the relationship between variables Profitability, company size, Raroc with stock selection decision is developed simultaneously which has a high determinant coefficient compared to partially.

The implication of this research for practitioners is that companies in LQ-45 maintain ROA, ROE and increase NPM which looks quite weak in shaping the company's profitability because it significantly affects stock selection decision. In addition, LQ- 45 companies limit Asset growth by increasing dividend distribution for investors because asset growth is not significant in increasing investor's stock selection decision. 


\section{RESEARCH LIMITATIONS}

1) The year of observation of this study is still limited from 2015-2017 and the number of samples of this study is still limited to the LQ45 Index and cannot describe the overall market conditions, for further research is expected to add to the research period and the number of research samples such as banking or manufacturing companies, so the results of research are more varied.

2) The variables studied are still limited to 3 independent variables such as; profitability, company size, and Raroc, so for the next study it is recommended to add other variables such as; cash dividend and earnings management are factors that influence stock selection decision, so the results of the study are broader (Tandelilin, 2010).

\section{REFERENCES}

Anisyah \& Purwohandoko (2017). Pengaruh profitabilitas, leverage, ukuran perusahaan dan struktur modalterhadap nilai perusahaan pada sektor pertambangan yang terdaftar pada bursa efek indonesia periode 2010-2015. Jurnal Manajerial Bisnis, 1(1), 34-46.

Bastian, Indra dan Suhardjono (2006). Akuntansi Perbankan. Jakarta: Salemba Empat. Brigham, E.F., \& Houston, J.F. (2014). Dasar-dasar Manajemen Keuangan. Jakarta: Salemba Empat.

Constantinou, G., Karali, A., \& Papanastasopoulos, G. (2017). Asset growth and the cross-section of stock returns: evidence from Greek listed firms. Management Decision, 55(5), 826-841. http://dx.doi.org/10.1108/MD-05-2016-0344.

Darmadji, T., \& Fakhruddin, H.M. (2011). Pasar Modal di Indonesia. Edisi Ketiga. Jakarta: Salemba Empat.

Dewi, A.S.M., \& Wirajaya, A. (2013). Pengaruh Struktur Modal, Profitabilitas dan Ukuran Perusahaan Pada Nilai Perusahaan. E-Jurnal Akuntansi Universitas Udayana, $4(2), 358-372$.

Fuss, C., \& Vermeulen, P. (2004). Firms' Investment decision In Response To Demand And Price Uncertainty. ECB Working Paper Series, 347.

Jagongo, A., \& Mutswenje, V.S. (2014). A Survey of the Factors Influencing Investment Decisions: The Case of Individual Investors at the NSE. International Journal of Humanities and Social Science, 4(4), 92-102.

Kasmir (2010). Analisis Laporan Keuangan. Jakarta: PT Raja Grafindo Persada.

Harahap, S.S. (2007). Analisis Kritis Atas Laporan Keuangan. Jakarta: PT Raja Grasindo Persada. 
Hermuningsih, S. (2012). Pengantar Pasar Modal Indonesia. Yogyakarta: UPP STIM YKPN.

Liestyana, R.A. (2008). Pengaruh Return On Equity (ROE) dan Earning Per Share (EPS) terhadap Harga Saham pada Industri Barang Konsumsi Periode 2002-2006. Bandung: Skripsi. Tidak Dipublikasikan, Fakultas Bisnis dan Manajemen Universitas Widyatama.

Mardiyanto, H. (2009). Intisari Manajemen Keuangan. Jakarta: PT Grasindo.

Nazir, M. (2014). Metode Penelitian. Cetakan 6. Bogor: Penerbit Ghalia Indonesia.

Nurmalasari, I. (2008). Analisis Pengaruh Rasio Profitabilitas Terhadap Harga Saham Emiten LQ45 Yang Terdaftar Di Bursa Efek Indonesia Tahun 2005-2008. Jakarta:Universitas Gunadarma.

Nofsinger, \& Richard (2002). Individual investments behavior. New York: McGraw-Hill.

Peltonen T. (2013). Fundamental Risk And Profitability: Evidence From High-Tech Companies. Espoo: Thesis Department Of Accounting Aalto University School Of Business.

Prabowo, H. (2013). Analisis portofolio saham dengan Metode Camp dan Markowitz. Binus Business Review, 4(1), 360-369.

Prokopczuk, M.S., Rachev, S., \& Trueck, S. (2004). Quantifying Risk In The Electricity Business: A RAROC - Based Approach. Energy Economics, 29(5).

Putra, R.A.D. (2014). Analisis Risiko dan Return Saham dengan Menggunakan Metode CAPM untuk Menentukan Pilihan Berinvestasi pada Saham LQ45 di BEI. Kota Malang: Universitas Brawijaya.

Rahmawati, A.D., Topowijono, \& Sulasmiyati, S. (2015). Pengaruh Ukuran Perusahaan, Profitabilitas, Struktur Modal, dan Keputusan Investasi Terhadap Nilai Perusahaan. JurnalAdministrasi Bisnis, 23(2), 1-7.

Ramarow, S. (2017). The Relationship between Profitability and the Risk Factors and other Macroeconomic Factors. Sintok: Universiti Utara Malaysia.

Rinati, I. (2009). Pengaruh Net Profit Margin (NPM), Return On Asset (ROA) Dan Return On Equity (ROE) Terhadap Harga Saham Pada Perusahaan Yang Tercantum Dalam Indeks LQ45. Bandung: Skripsi. Program Sarjana Universitas Gunadarma.

Riyanto, B. (2008). Dasar-Dasar Pembelanjaan Perusahaan. Edisi keempat, Yogyakarta: BPFE.

Shefrin, H. (2000). Beyond Greed and Fear: Understanding Behavioral Finance and the Psychology of Investing. Boston: Harvard Business School Press.

Samsul, M. (2006). Pasar Modal dan Manajemen Portofolio. Surabaya: Erlangga.

Sartono, A. (2010). Manajemen Keuangan Teori dan Aplikasi. Edisi Keempat. Yogyakarta: BPFE.

Sudarmadji, A.M., \& Sularto, L. (2007). Pengaruh Ukuran Perusahaan, Profitabilitas Leverage, dan Tipe Kepemilikan Perusahaan Terhadap Luas Voluntary Disclosure Laporan Keuangan Tahunan. Proceeding PESAT, 2, A53-A60.

Sunariyah, S.E. M.Si. (2006). Pengantar Pengetahuan Pasar Modal. Edisi Kelima. Yogyakarta: UPP STIM YKPN.

Tandelilin, E. (2010). Portofolio dan Investasi Teori dan Aplikasi. Edisi Pertama. Yogyakarta: Kanisius. 
Weston, F.J., \& Brigham, E.F. (2001). Dasar - Dasar Manajemen Keuangan. Edisi 9. Jakarta: Erlangga.

Yulindar, S.N. (2017). Pengaruh Ukuran Perusahaan dan Profitabilitas Terhadap Nilai Perusahaan Pada PT Semen Indonesia TBK. Jurnal Ilmu dan Riset Manajemen, 6(9).

(www1) Saham OK, http://www.sahamok.com (accessed: 1.07.2018).

(www2) IDX, http://www.idx.co.id (accessed 3.07.2018). 